\title{
Fecal Calprotectin Levels in the Babies with Infantile Colic
}

\section{infantil Kolikli Bebeklerde Dışkıda Kalprotektin Düzeyleri}

\author{
Nalan Karabayır ${ }^{1}$ (D) Tülin A. Özden $^{2}$ (D), Özlem Durmaz² (D), Gülbin Gökçay ${ }^{3}$ (D) \\ ${ }^{1}$ Istanbul Medipol University, International School of Medicine, Department of Pediatrics, Istanbul, Turkey \\ ${ }^{2}$ Istanbul University, Istanbul Faculty of Medicine, Department of Pediatric Gastroenterology, Istanbul, Turkey \\ ${ }^{3}$ istanbul University, Child Health Insitute Department of Social Pediatrics, Istanbul, Turkey
}

ORCID ID: N.K. 0000-0002-8003-1952; T.A.Ö. 0000-0001-9952-803X; Ö.D. 0000-0001-6969-9962; G.G. 0000-0003-1042-0407

Citation/Attf: Karabayir N, Ozden TA, Durmaz O, Gokcay G. Fecal calprotectin levels in the babies with infantile colic. Çocuk Dergisi - Journal of Child 2021;21(2):105-110. https://doi.org/10.26650/jchild.2021.775736

ABSTRACT

Objective: Excessive crying is one of the most common complaints in the first months of life. Although various theories have been proposed to explain infantile colic, the etiology is still unclear. The aim of this study is to measure fecal calprotectin levels in infants with and without infantile colic and to investigate their possible relationship with inflammation. Methods: Infants attending a General Pediatrics Clinic in Medipol Mega University Hospital constituted the study population. Fecal calprotectin levels were measured using the Elisa Method in a total of 70 infants aged 1-3 months, 35 of which had infantile colic. A total of 42 infants, 22 of whom were in the colic group and 20 of them in the control group were followed for one year.

Results: The socio-demographic features and feeding types of the infants with or without infantile colic were similar. Fecal calprotectin levels were significantly higher in the colicky babies, and all had calprotectin levels > $250 \mu \mathrm{gr} / \mathrm{g}$. The median fecal calprotectin values of the colic and control groups were $651 \mu \mathrm{gr} / \mathrm{g}$ and $354 \mu \mathrm{gr} / \mathrm{g}$, respectively. No significant difference was found between the cases where the calprotectin levels were higher or lower than $350 \mu \mathrm{g} / \mathrm{g}$ in terms of birth weight, gender, mode of delivery, diet and use of probiotics. During the follow-up, symptoms of food allergy occurred in 4 patients in the control group and in 3 patients in the study group.

Conclusion: High fecal calprotectin levels in the colic infants suggest that infantile colic and intestinal inflammation may be associated.

Keywords: Crying, calprotectin, infant, infantile colic, intestinal inflammation öz

Amaç: Doğumu izleyen ilk üç ayda aşırı ağlama çok sık rastlanan bir yakınmadır. Infantil kolik etyolojisi kesin olarak aydınlatılamamıştı. Son yıllarda intestinal mikrobiyatadaki değişikliklerin koliğe neden olabileceği ileri sürülmektedir. Çalışmamızın amacı dışkıda kalprotektin düzeylerinin ölçülerek kolik ile intestinal inflamasyon ilişkisinin araştııılmasıdır.

Gereç ve Yöntem: Medipol Mega Üniversite hastanesi Genel Pediatri Polikliniğinde yapılan çalışmada 1-3 ay arası infantil kolikli 35 bebek (çalışma grubu) ile koliği olmayan 35 bebek olmak üzere toplam 70 bebeğin dışkıda kalprotektin düzeyleri iÜ Çocuk Gastroenteroloji Laboratuarında Elisa yöntemiyle ölçüldü. Kolik grubunda 22, kontrol grubunda 20 olmak üzere toplam 42 bebek bir yıl boyunca izlendi.

Bulgular: Çalışma ve kontrol grubu bebekleri doğum tartısı, cins, doğum şekilleri, beslenme biçimleri açısından karşılaştırıldığında iki grup arasında fark saptanmadı. Çalışma grubunda kalprotektin düzeyleri anlamlı derecede yüksek olup, tüm olgularda fekal kalprotektin düzeyleri $>250$ $\mu \mathrm{gr} / \mathrm{g}$ bulundu. Çalışma grubunun median kalprotektin değeri 651 $\mu \mathrm{gr} / \mathrm{g}$ kontrol grubunun median değeri ise $354 \mu \mathrm{gr} / \mathrm{g}$ ölçüldü. Kalprotektin düzeyleri $350 \mu \mathrm{gr} / \mathrm{g}$ 'den yüksek ve düşük olan olgular arasında doğum tartısı, cins, doğum şekli, beslenme biçimi ve probiyotik kullanımı açısından anlamlı fark saptanmadı. Takipte kontrol grubunda 4, çalışma grubunda 3 olgu besin alerjisi tanısı aldı.

Sonuç: Kolik bebeklerde yüksek dışkı kalprotektin seviyeleri, infantil kolik ve intestinal inflamasyonun ilişkili olabileceğini düşündürmektedir.

Anahtar Kelimeler: Ağlama, infantil kolik, intestinal enflamasyon, kalprotektin, süt çocuğu

Corresponding Author/Sorumlu Yazar: Nalan Karabayır E-mail: nalankarabayir@hotmail.com

Submitted/Başvuru: 30.07.2020 • Revision Requested/Revizyon Talebi: 30.10.2020 • Last Revision Received/Son Revizyon: 20.11.2020 •

Accepted/Kabul: 13.07.2021 


\section{INTRODUCTION}

Infantile colic is challenging for parents and is a cause of 10 to $20 \%$ of visits during the first weeks of life. Despite much research, the etiology of infantile colic has not been fully understood (1). It has been suggested that fermentation caused by the excess of intestinal coliform bacteria, especially E. coli, may cause abdominal pain in colicky babies due to excessive gas and increased motility (2-4). In some studies, it was reported that infantile colic may be associated with intestinal inflammation. The high value of fecal calprotectin, which is released in stools in response to mucosal inflammation in infants with infantile colic can support the hypothesis that dysbiosis and inflammatory state may cause infantile colic $(5,6)$. The aim of our study was to investigate the relationship between infantile colic and intestinal inflammation by measuring the fecal calprotectin levels.

\section{METHODS}

\section{Context and population}

This study was carried out at Medipol Mega University Hospital between March 2014 and May 2015. All infants aged 1-3 months seen consecutively in the General Pediatrics Clinic were eligible for the study. At the beginning of the study, parents completed a short questionnaire containing clinical and demographic information. The gestation week, birth weight, gender, age, delivery method, breastfeeding, starting time (postnatal week) of colic and the use of probiotics in appropriate doses for more than a week were recorded. Breastfeeding patterns of the infants were classified according to the description made by Labbok et al. (7).

During the study period, 522 consecutive infants aged 1-3 months were brought consecutively to the outpatient unit for various reasons. Wessel criteria was used for the definition of infantile colic (8). All infants had whole urinary analysis and urinary culture to exclude urinary infection. All babies to be included in the study were selected according to the criteria shown in Table 1. The parents of all 232 infants who complied with the inclusion criteria were encouraged to participate in

Table 1: Inclusion criteria for the study.

Being a term infant (gestation $>37+6 / 7$ weeks)

Birth weight $>2500$ gr

Gaining at least $20 \mathrm{gr}$ weight per day

Absence of major congenital malformation or metabolic disease

Absence of the history of hospitalization due to infection or the history of antibiotic use,

Absence of rectal bleeding or doctor-diagnosed allergy in the family, No allergy symptoms related to the respiratory tract and/or skin,

No abdominal distention due to meteorism alone or together with diaper dermatitis,

Absence of urinary infection

No symptoms suggestive of gastroesophageal reflux the study. The parents of 138 declined to participate. It was possible to take stool samples from 37 infants with colic, and 35 infants were included in the study group since the sample quantity was insufficient in 2 of those samples. In 41 of the cases without colic (control group), the families agreed to participate in the study and samples were taken from 36 infants. The calprotectin levels were studied in 35 of these cases since the sample amount was insufficient in 1 of these infants (Figure 1).

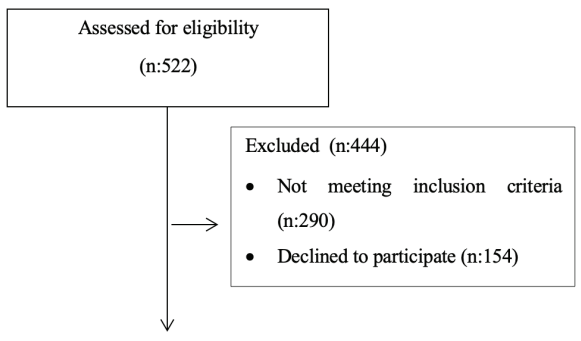

Study population (n:78)

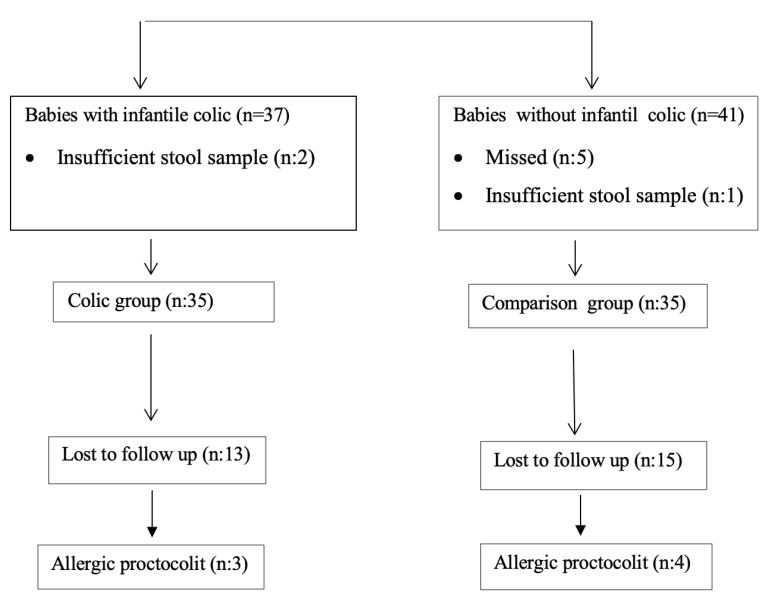

Figure 1: Flow diagram of the sample collection and analysis.

Written consent was received from the families who participated in the study. Istanbul Medipol University ethics committee approval was obtained (2013/14) and the study was funded by the researcher.

Total of 42 infants, 22 of whom were in the colic group and 20 of them in the control group were followed for one year. During the follow-up, a diagnosis of allergic proctocolitis was made when bloody stools were detected in a total of 7 infants, 3 of whom were in the colic group and 4 in the control group, who were fed exclusively with breast milk.

\section{Study procedures and sample collections}

The families were asked to bring fresh stool samples taken directly from the babies' diapers into tubes to Medipol Mega University Hospital Biochemistry laboratory on the same day. These stool samples were stored in a polyethylene tube at $-40^{\circ} \mathrm{C}$ in accordance with the manufacturer's instructions. The stool samples were tested at the Istanbul Medical Faculty's Children Gastroenterology and Trace Elements Laboratory at Istanbul 
University. The samples were transferred to a $-20^{\circ} \mathrm{C}$ storage cabinet to thaw slowly before the analysis. Stool samples were kept at $2-8^{\circ} \mathrm{C}$ the night before analysis, then stored at room temperature until testing. The stool samples were analyzed with the ELISA PhilCal Calprotectin Elisa Kit (Stubenwald-Alee 8a D-64625 Bensheim). The results were presented as $\mu \mathrm{g} / \mathrm{g}$ stool. Each baby had one stool sample analyzed.

As reference values for children under 4 years of age are unknown, we decided to compare the proportion of infants with values above $350 \mu \mathrm{gr} / \mathrm{g}$ in the two groups, based on the values suggested by Ezri et al. (9).

\section{Statistical analysis}

SPSS 22.0 (Statistical Package for the Social Science, Inc.; Chicago, $\mathrm{IL}, \mathrm{ABD}$ ) program was used for statistical analysis. Mean, standard deviation (SD), median, minimum, maximum, frequency and ratios were used in the descriptive statistics of the data. The distribution of variables was evaluated using the Kolmogorov Simirnov test and the Mann-Whitney $U$ test was used in the analysis of quantitative data. The Chi-square test was used in the analysis of qualitative data, and the Fisher test was used when the required conditions of the chi-square test were not met. A $p$ value of $<0.05$ was considered significant. The effect of the selected threshold value was investigated with the ROC curve.

\section{RESULTS}

The baseline characteristics of the included infants are given in Table 2. Of all the infants, one was fed with breast milk+formula and 69 infants were fed only with breast milk. The number of babies fed with breast milk above the average may be related to the presence of a breastfeeding counseling clinic in same hospital. Calprotectin levels varied between $132 \mu \mathrm{gr} / \mathrm{gr}$ and $1708 \mu \mathrm{gr} / \mathrm{g}$; the median value was found to be $574 \mu \mathrm{gr} / \mathrm{gr}$. Fecal calprotectin levels were above 350 $\mathrm{gr} / \mathrm{gr}$ in 53 infants. Infants' characteristics in two groups are given in Table 3.

There was no significant difference between the study and control groups in terms of gender, mode of delivery and feeding type.

Probiotic use was $37 \%$ in the colic group and $3 \%$ in the control group, the difference was statistically significant $(p<0.001)$.

Calprotectin levels of babies with colic were found to be significantly higher than babies in the control group (Table 3 ).

No association was found between fecal calprotectin level and other baseline characteristics. The calprotectin level was found to be $\geq 350 \mu \mathrm{gr} / \mathrm{gr}$ in $91 \%$ of all infants with colic and was $57 \%$ in the control group. The difference between the two groups was found to be significant ( $p=0.003$ ) (Table 4 and 5 ).

In the evaluation of infants with and without colic, it was found that the threshold value of $350 \mu \mathrm{gr} / \mathrm{g}$ of calprotectin was significant [0.678 (0.549-0.806)]. Sensitivity, specificity, positive predictive value and negative predictive value were found to be $62.7 \%, 91.4 \%, 83.3 \%$ and $44.1 \%$, respectively (Table 6).

During one year follow-up, 3/35 infants in the "colic" group and 4/35 in the "control" group were diagnosed as having a food allergy. Fecal calprotectin level was above $500 \mu \mathrm{gr} / \mathrm{g}$ in all babies with allergies, and it was found that it was $>1000 \mu \mathrm{gr} / \mathrm{g}$ in 5 of these babies.

Table 2: Characteristics of the infants in the study.

\begin{tabular}{|c|c|c|c|c|c|}
\hline & & Min-Max & Median & \multicolumn{2}{|c|}{ mean.tss / n-\% } \\
\hline Age (d) & & $29-92$ & 47 & \multicolumn{2}{|c|}{$49.5 \pm 15.5$} \\
\hline Birthweight(g) & & $2680-4290$ & 3280 & \multicolumn{2}{|c|}{$3362.1 \pm 420.5$} \\
\hline Gestation week & & $38-41$ & 39 & \multicolumn{2}{|c|}{$38.9 \pm 0.7$} \\
\hline \multirow{2}{*}{ Gender } & Girl & & & 30 & 42.8 \\
\hline & Boy & & & 40 & 77.2 \\
\hline \multirow{2}{*}{ Feeding type } & Breastmilk & & & 69 & 98.6 \\
\hline & Breastmilk + Formula & & & 1 & 1.4 \\
\hline \multirow{2}{*}{ Delivery type } & Normal spontaneous delivery & & & 15 & 21.4 \\
\hline & Cesarian section & & & 55 & 78.6 \\
\hline \multirow{2}{*}{ Probiotic use } & Yes & & & 14 & 20.0 \\
\hline & No & & & 56 & 80.0 \\
\hline \multirow{2}{*}{ Atopy } & No & & & 35 & 83.4 \\
\hline & Yes & & & 7 & 16.6 \\
\hline Calprotectin & & $132-1708$ & 574 & \multicolumn{2}{|c|}{$647.3 \pm 402.3$} \\
\hline \multirow{2}{*}{ Calprotectin } & $<350$ & & & 17 & 24.2 \\
\hline & $\geq 350$ & & & 53 & 75.8 \\
\hline \multirow{2}{*}{ Colic } & $(-)$ & & & 35 & 50.0 \\
\hline & $(+)$ & & & 35 & 50.0 \\
\hline
\end{tabular}


Table 3: Comparison of infants' characteristics in two groups.

\begin{tabular}{|c|c|c|c|c|c|c|c|}
\hline & \multicolumn{3}{|c|}{ Comparison group } & \multicolumn{3}{|c|}{ Colic group } & \multirow[b]{2}{*}{ p } \\
\hline & \multicolumn{2}{|c|}{ Mean $\pm S d / n-\%$} & Med (min-max) & \multicolumn{2}{|c|}{ Mean $\pm S d / n-\%$} & Med (min-max) & \\
\hline Age $(d)^{*}$ & \multicolumn{2}{|c|}{$52.1 \pm 17.7$} & & \multicolumn{2}{|c|}{$47.0 \pm 12.9$} & & 0.291 \\
\hline Birth weight $(w)^{*}$ & \multicolumn{2}{|c|}{$3256 \pm 385$} & & \multicolumn{2}{|c|}{$3468 \pm 433$} & & 0.36 \\
\hline Gestation week* & \multicolumn{2}{|c|}{$39 \pm 1$} & & \multicolumn{2}{|c|}{$39 \pm 1$} & & 0.400 \\
\hline \multicolumn{8}{|l|}{ Feeding type** } \\
\hline Breastmilk & 35 & 100 & & 34 & $97 \%$ & & 1.000 \\
\hline Breastmilk+Formula & 0 & 0 & & 1 & $3 \%$ & & \\
\hline \multicolumn{8}{|l|}{ Probiotic using** } \\
\hline Yes & 34 & $99 \%$ & & 22 & $63 \%$ & & 0.000 \\
\hline No & 1 & $1 \%$ & & 13 & $37 \%$ & & \\
\hline \multicolumn{8}{|l|}{ Food allergy** } \\
\hline No & 31 & $88.5 \%$ & & 32 & $91 \%$ & & 0.660 \\
\hline Yes & 4 & $11.5 \%$ & & 3 & $9 \%$ & & \\
\hline Calprotectin $(\mu \mathrm{gr} / \mathrm{dl})^{* *}$ & \multicolumn{2}{|c|}{$560 \pm 459$} & $354(132-1708)$ & \multicolumn{2}{|c|}{$732 \pm 323$} & $651(273-1689)$ & 0.000 \\
\hline$<350$ & 15 & $43 \%$ & & 3 & $9 \%$ & & 0.003 \\
\hline$\geq 350$ & 20 & $57 \%$ & & 32 & $91 \%$ & & \\
\hline
\end{tabular}

*Mann-Whitney U test, ${ }^{* *}$ Chi-Square test

Table 4: Comparison of the babies with calprotectin levels $<350$ and $\geq 350$.

\begin{tabular}{lcccccc}
\hline & \multicolumn{2}{c}{ Calprotectin $<350$} & \multicolumn{2}{c}{ Calprotectin $\geq 350$} & P \\
\cline { 2 - 5 } & mean \pm std & Min-Max & mean \pm std & Min-Max & \\
\hline Age (d) & $55.6 \pm 20.0$ & $29.0-92.0$ & $47.4 \pm 13.2$ & $30.0-85.0$ & 0.157 \\
Birthweight(g) & $3347 \pm 431$ & $2720-4150$ & $3367 \pm 421$ & $2680-4290$ & 0.808 & 0.471 \\
Gestation week & $38.8 \pm 0.7$ & $38.0-40.0$ & $38.9 \pm 0.7$ & $38.0-40.9$ & \\
\hline
\end{tabular}

*Mann-Whitney $\mathrm{U}$ test

Table 5: Characteristics of infants according to the calprotectin levels.

\begin{tabular}{|c|c|c|c|c|c|c|}
\hline & & \multicolumn{2}{|c|}{ Calprotectin $<350$} & \multicolumn{2}{|c|}{ Calprotectin $\geq 350$} & \multirow{2}{*}{$\mathbf{p}^{*}$} \\
\hline & & $\mathrm{n}$ & $\%$ & $\mathbf{n}$ & $\%$ & \\
\hline \multirow{2}{*}{ Gender } & Girl & 9 & 53 & 21 & 40 & \multirow{2}{*}{0.516} \\
\hline & Boy & 8 & 47 & 32 & 60 & \\
\hline \multirow{2}{*}{ Delivery type } & Normal spontaneous labor & 3 & 17 & 11 & 21 & \multirow{2}{*}{0.954} \\
\hline & Cesarean section & 14 & 83 & 42 & 79 & \\
\hline \multirow{2}{*}{ Feeding } & Breastmilk & 17 & 100 & 52 & 99 & \multirow{2}{*}{1.000} \\
\hline & Breastmilk+formula & 0 & 0 & 1 & 1 & \\
\hline \multirow[b]{2}{*}{ Probiotic using } & Yes & 2 & 12 & 12 & 23 & \multirow[b]{2}{*}{0.260} \\
\hline & $\mathrm{No}$ & 15 & 88 & 41 & 77 & \\
\hline \multirow[b]{2}{*}{ Atopy } & No & 17 & 100 & 46 & 86 & \multirow[b]{2}{*}{0.177} \\
\hline & Yes & 0 & 0 & 7 & 14 & \\
\hline
\end{tabular}

${ }^{*}$ Chi-Square test 
Table 6: Association between fecal protectin $>350 \mathrm{gr} / \mathrm{g}$ and a diagnosis of infantile colic.

\begin{tabular}{lccc}
\hline & Under curve area & 95\% GA & P \\
\hline Calprotectin & 0.705 & $0.570-0.840$ & $\mathbf{0 . 0 0 3}$ \\
Cut-off level 350 & 0.678 & $0.549-0.806$ & $\mathbf{0 . 0 1 1}$ \\
Sensitivity & $62.7 \%$ & \\
Positive predictive value & $91.4 \%$ & \\
Sensitivity & $83.3 \%$ & \\
Negative predictive value & $44.1 \%$ & \\
\hline
\end{tabular}

\section{DISCUSSION}

The etiology of infantile colic, which is common in the first months of life, is not fully understood. In recent years, there has been increasing evidence suggesting that infantile colic is associated with intestinal inflammation $(6,10)$. Analysis of fecal calprotectin levels in these cases is important for evaluating the presence of intestinal inflammation in the etiology (11). For this purpose, in our study calprotectin levels were investigated in infants with colic.

To the best of our knowledge, our study of exclusively breastfed babies represents the largest sample in the literature. In our study, fecal calprotectin levels were found to be significantly higher in infants with colic than in the control group. Four previous studies have evaluated the possible association between fecal calprotectin levels and infantile colic. In a study comparing 19 colic and 17 non-colic infants, it was found that calprotectin levels were high in colic infants regardless of feeding (12). In another study such a difference was not reported. No information about the dietary patterns of infants was given in this study (13). In a study conducted in 37 infants with colic and 28 non-colic infants, calprotectin levels were significantly higher in infantile colic infants. In this study, babies were fed with breast milk, partial breast milk or formula (10). In a study of 87 infants who were exclusively or predominantly breastfed, fecal calprotectin levels were found to be higher in colic infants than control group (14). In our study all infants were breast-fed except one baby.

Fecal calprotectin levels are affected by many factors. In children, intestinal inflammation such as bacterial gastroenteritis, rectal bleeding, cirrhosis, polyps or cancerous lesions, use of salicylate and non-steroidal anti-inflammatory drugs may increase calprotectin levels (15). It has been reported that calprotectin was $89 \%$ sensitive and $79 \%$ specific in separating organic and non-organic causes in children examined for chronic abdominal pain (16). Also, it has been found that the calprotectin level in babies is higher than in older children $(9,17,18)$. The median fecal calprotectin value for babies aged between 0-3 months was found to be $345 \mathrm{mg} /$ $\mathrm{kg}$ in one study (9). Oord et al. reported that in children aged 1-6 months, the median value was $538 \mathrm{mg} / \mathrm{kg}$ and it has been reported that values below $350 \mu \mathrm{gr} / \mathrm{g}$ should be considered normal (19). Rugtveit et al. reported that mean calprotectin levels were $269 \mu \mathrm{g} / \mathrm{g}$ and $264 \mu \mathrm{gr} / \mathrm{g}$ in 6-week-old and 3-monthold infants, respectively (20). In a study carried out in Turkey, the median calprotectin value in infants in the neonatal period was $589.5 \mu \mathrm{gr} / \mathrm{g}$, while this value was found to be $304 \mu \mathrm{gr} / \mathrm{g}$ in babies aged 31-180 days (21). Dietary factors have also been reported to affect infants' calprotectin levels in some studies (14). Dorosko et al and Savino et al. reported high calprotectin levels among breastfed infants, whereas Campeotto et al. reported no differences $(14,22,23)$.

Intestinal inflammation may be associated with geographic location, hygiene conditions and dietary routines (24). Therefore, the differences in the studies may be due to environmental and genetic factors (21). In our study, carried out with term healthy and all but one breastfed 1-3-month-old infants, the median calprotectin level in the comparison group was $354 \mu \mathrm{gr} / \mathrm{g}$, which is consistent with the literature $(9,19)$.

Although interpretation of fecal calprotectin levels in infants is difficult due to the lack of reference values in infants, we found higher values and a greater proportion with levels $>350 \mu \mathrm{gr} / \mathrm{g}$ in the group with infantile colic compared to infants in the control group. These findings indicate that infantile colic may be associated with intestinal inflammation. In our study, high fecal calprotectin levels in colic infants support this relationship. In addition, as far as we know, our study is the first study carried out on fecal calprotectin levels in infants with infantile colic in Turkey. The limitations of our study are that valid reference limits for children younger than 4 years are not known and the cross-sectional nature of the study. Further studies are needed to examine this hypothesis and establish whether there is a place for fecal calprotectin testing in the diagnostic work up of infants presenting with infantile colic.

Ethics Committee Approval: This study was approved by the ethics committee of Istanbul Medipol University (2013/14).

Informed Consent: Written consent was obtained from the participants.

Peer Review: Externally peer-reviewed.

Author Contributions: Conception/Design of Study- G.G., Ö.D.; Data Acquisition- N.K.; Data Analysis/Interpretation- N.K., G.G., T.Ö.; Drafting Manuscript- N.K., G.G., T.Ö.; Final Approval and Accountability- N.K., G.G.

Conflict of Interest: Authors declared no conflict of interest.

Financial Disclosure: Authors declared no financial support.

Etik Komite Onayı: Çalışma için İstanbul Medipol Üniversitesi Etik Kurulu'ndan onay alınmıştı (2013/14).

Bilgilendirilmiş Onam: Katılımcılardan bilgilendirilmiş onam alınmıştır. Hakem Değerlendirmesi: Dış bağımsız.

Yazar Katkıları: Çalışma Konsepti/Tasarım- G.G., Ö.D.; Veri ToplamaN.K.; Veri Analizi/Yorumlama- N.K., G.G., T.Ö.; Yazı Taslağı- N.K., G.G., T.Ö.; Son Onay ve Sorumluluk- N.K., G.G. 
Çıkar Çatışması: Yazarlar çıkar çatı̧̧ması beyan etmemişlerdir.

Finansal Destek: Yazarlar finansal destek beyan etmemişlerdir.

\section{REFERENCES}

1. Pankaj G. Infantil Colic-Unfolded. Indian J Pediatr 2004;71:903-6.

2. Rhoads JM, Fatheree NY, Norori JLiu, Lucke JF, Tyson JE, Ferris MJ. Altered fecal microflora and increased fecal calprotectin in infants with colic. J Pediatr 2004;155:823-8.

3. Johnson JD, Cocker K, Chang E. Infantile Colic: Recognition and Treatment. Am Fam Physician 2015;92:577-82.

4. Vandenplas $Y$, Alarcon P. Updated algorithms for managing frequent gastro-intestinal symptoms in infants. Beneficial Microbes 2015;6:199-208.

5. Pärtty A, Kalliomäki M, Salminen S, Isolauri E. Infantile colic is associated with low-grade systemic inflammation. J Pediatr Gastroenterol Nutr 2017;64:691-5.

6. Savino F, Garro M, Montanari P, Galliano I, Bergallo M. Crying Time and RORY/FOXP3 Expression in Lactobacillus reuteri DSM17938-Treated Infants with Colic: Randomized Trial. J Pediatr 2018;192:171-7.

7. Labbock M, Krasovec K. Toward consistency in breastfeeding definitions. Stud Fam Plann 1990;21:226230.

8. Wessel MA, Cobb JC, Jackson EB, Harris GS Jr, Detwiller AC. Paroxysmal fussing in infancy, sometimes called colic. Pediatrics 1954;14:421-35.

9. Ezri J, Nydegger A. Fecal calprotectin in children use and interpretation. Rev Med Suisse 2011;7:69-70.

10. Rhoads JM, Collins J, Fatheree NY, Hashmi S, Taylor CM, Luo M. et al. Infant Colic Represents Gut Inflammation and Dysbiosis. J Pediatr 2018;203:55-61.

11. Nocerino R, De Filippis F, Cecere G, Marino A, Micillo M, Di Scala C, et al. The therapeutic efficacy of Bifidobacterium animalis subsp. lactis BB- $12^{\circledR}$ in infant colic: A randomised, double blind, placebocontrolled trial. Aliment Pharmacol Ther 2020;51:110-20.

12. Rhoads JM, Fatheree NY, Norori JLiu, Lucke JF, Tyson JE, Ferris MJ. Altered fecal microflora and increased fecal calprotectin in infants with colic. J Pediatr 2009;155:823-8.
13. Olafsdottir E, Aksnes L, Fluge G, Berstad A. Faecal calprotectin levels in infants with infantile colic, healthy infants, children with inflamatory bowel disease, children with recurrent abdominal pain and healthy children. Acta Paediatr 2002;91:45-50.

14. Savino F, Castagno E, Calabrese R, Viola S, Oggero R, Miniero R, et al. High faecal calprotectin levels in healthy,exclusively breast-fed infants. Neonatology 2010;97:299-304.

15. Saha A, Tighe MP, Batra A. How to use faecal calprotectin in management of paediatric inflammatory bowel disease. Arch Dis Child Educ Pract Ed 2016;101:124-8.

16. Carroccio A, lacono G, Cottone M, Di Prima L, Cartabellotta F, Cavataio F, et al. Diagnostic accuracy of fecal calprotectin assay in distinguishing organic causes of chronic diarrhea from irritable bowel syndrome: a prospective study in adults and children. Clin Chem 2003;49(6 Pt 1);861-7.

17. Hestvik E, Tumwine JK, Tylleskar T, Grahnquist L, Ndeezi G, Kaddu-Mulindwa DH, et al. Faecal calprotectin concentrations in apparently healthy children aged 0-12 years in urban Kampala, Uganda: a community-based survey. BMC Pediatr 2011;11:9.

18. Kapel N, Campeotto F, Kalach N, Baldassare M, Butel MJ, Dupont C. Faecal calprotectin in term and preterm neonates. J Pediatr Gastroenterol Nutr 2010;51:542-7.

19. Oord T, Hornung N. Fecal calprotectin in healthy children. Scand J Clin Lab Invest 2014;74:254-8.

20. Rugtveit J,Fagerhol MK. Age-dependent variations in fecal calprotectin concentrations in children. J Pediatr Gastroenterol Nutr 2002;34:323-4.

21. Sahin Gunaydin BS, Keskindemirci G, Ozden TA, Durmaz O, Gokcay $G$. Faecal calprotectin levels during the first year of life in healthy children. J Paed Child Health 2020.

22. Dorosko SM, Mackenze T, Connor RI. Fecal calprotectin concentrations are higher in exclusively breatfed infants compared to those who are mixed-fed. Breasfeeding Med 2008;3:117-9.

23. Campeotto F, Butel MJ, Kalach N, Derrieux S, Aubert-Jacquin C, Barbot L, et al. High faecal calprotectin concentrations in newborn infants. Arch Dis Child Fetal Neonatal ed 2004;89:353-5.

24. Castro F, de Souza HSP. Dietary Composition and Effects in Inflammatory Bowel Disease. Nutrients 2019;11:1398. 